\title{
Determination of Organic Acids in Natural and Commercial Orange Juices by HPLC/DAD
}

\section{Doğal ve Ticari Portakal Sularındaki Organik Asitlerin HPLC/DAD Yöntemiyle Tayini}

\author{
Research Article \\ Ebru Büyüktuncel*, Özlem Kalkan and Emine Şahin \\ Inönü University, Faculty of Pharmacy, Department of Analytical Chemistry, Malatya, Turkey.
}

\section{A B S T R AC T}

\begin{abstract}
This study aimed to develope a simple reversed-phase HPLC method for simultaneous determination of organic acids in natural and commercial orange juices. The chromatographic separation of these compounds was performed in a single run by using isocratic mobile phase consisting of $10 \mathrm{mM} \mathrm{KH}_{2} \mathrm{PO}_{4}(\mathrm{pH}=2.2)$ at room temperature, with flow rate of $1 \mathrm{~mL} \cdot \mathrm{min}^{-1}$ within $10 \mathrm{~min}$ on Inertsil ODS-4 C18 column $(250 \times 4.0 \mathrm{~mm}, 5 \mu \mathrm{m})$. An ultraviolet absorption at $210 \mathrm{~nm}$ and $245 \mathrm{~nm}$ was monitored. Linearity of calibration, accuracy, precision were examined as parts of the method validation. It has been found that the levels of organic acids in natural juices were higher than in commercial juices.
\end{abstract}

\section{Key Words}

Determination of organic acids, orange juices, HPLC/DAD.

\section{Ö z}

u çalışma, doğal ve ticari portakal sularında, organik asitlerin eş zamanlı olarak tayini için basit bir ters faz HPLC yöntemi geliştirmeyi amaçlamıştır. Bileşiklerin kromatografik ayrımı izokratik olarak $10 \mathrm{mM}$ $\mathrm{KH}_{2} \mathrm{PO}_{4}(\mathrm{pH}=2.2)$ hareketli fazıyla, oda sıcaklığında, $1 \mathrm{~mL}$. min ${ }^{-1}$ akış hızında, 10 dakika içinde ve Inertsil ODS4 C18 kolonda $(250 \times 4.0 \mathrm{~mm}, 5 \mu \mathrm{m})$, gerçekleşmiştir. Ultraviyole absorpsiyon 210 ve $245 \mathrm{~nm}$ dalgaboyunda izlenmiştir. Doğrusallık, doğruluk, kesinlik gibi parametreler belirlenerek yöntem valide edilmiştir. Doğal meyve sularındaki organik asit seviyesinin, ticari meyve sularından daha yüksek olduğu bulunmuştur.

\section{Anahtar Kelimeler}

Organik asit tayini, portakal suları, HPLC/DAD.

Article History: Received: Mar 27, 2017; Revised: Jul 8, 2017; Accepted: Oct 20, 2017; Available Online: Dec 25, 2017. DOI: 10.15671/HJBC.2018.182

Correspondence to: E. Büyüktuncel, İnönü University, Faculty of Pharmacy, Department of Analytical Chemistry, Malatya, Turkey. 


\section{INTRODUCTION}

The identification and determination of organic acids in fruit juices is considered very important for their quality and process controls [1]. The concentration of organic acids in fruits are important, because they influence the organoleptic properties of fruit juices particularly as regards flavour, colour and aroma [2]. The content organic acids in fruit juices not only influences organoleptic properties but also their stability, nutrition, acceptability and quality [3]. Content of organic acids, additives or preservatives in natural fruit juices and commercial juices are different [4]. Several chromatographic methods have been developed for identifying and quantifying individually organic acids in different matrixes. Kotani et al. determined organic acids in fruit wines by highperformance liquid chromatography (HPLC) with electrochemical detection (ED) within 20 min on an ion-exclusion column [5]. Flores et al., used liquid chromatography coupled to tandem-mass spectrometry (LC-MS/MS) with triple quadrupole in selective reaction monitoring mode to determine organic acids (glutamic, tartaric, quinic, malonic, malic, shikimic, a-ketoglutaric, pyruvic, citric, succinic and fumaric acids) in fruits (melon, grape, peach, orange, lemon) and vegetables (green and red pepper, tomato, lettuce and lamb's lettuce). The mobile phase was $0.1 \%(\mathrm{v} / \mathrm{v})$ formic acid at a flow rate of $0.4 \mathrm{~mL} \cdot \mathrm{min}^{-1}$. Organic acids eluted in less than 15 min [6]. Chinnici et al., separated nine acids (including oxalic, citric, malic, quinic, galacturonic, ascorbic, succinic, and fumaric acid) and three sugars (sucrose, glucose and fructose) by ion-exclusion chromatography using a resin based Aminex HPX $87 \mathrm{H}$ column. They obtained best separation with $0.005 \mathrm{~N}$ phosphoric acid as eluent in less than 20 min [7]. Sherer et al., developed a fast liquid chromatographic method for simultaneous determination of tartaric, malic, ascorbic and citric acids in fruits and juices. The method was fast and leaded to the organic acids separation in a 10 min run. They evaluated the six industrialized juices and three of them were not in accordance with the Brazilian legislation with respect to the values declared on the label [2]. Kelebek et al., determined organic acids, sugars, phenolic compositions and antioxidant capacities of orange juice and orange wine obtained from the cv. Kozan of Turkey. They used high-performance liquid chromatographic methods to identify and quantify of three organic acids (citric, malic and ascorbic acids). They analyzed sugars and organic acids were simultaneously onto an Aminex HPX$87 \mathrm{H}$ column $(300 \times 7.8 \mathrm{~mm})[8]$.

The goal of our research is the optimization and validation of a rapid method for simultaneous determination of the major organic acids in natural or commercial juices of orange fruit.

\section{MATERIALS and METHODS}

\section{Reagents and Materials}

Standard substances of oxalic acid, tartaric acid, malic acid, ascorbic acid, lactic acid, acetic acid, citric acid, fumaric acid were purchased from Sigma-Aldrich (St. Louis, MO, USA). All solvents and reagents that are used in this study were HPLC or of analytical grade. Water was purified (18 $\mathrm{M} \Omega$ $\mathrm{cm}^{-1}$ quality) from New Human Power I (Korea).

\section{Standard Solutions}

Stock standard solutions of fumaric acid, oxalic acid and ascorbic acid were dissolved in ultrapure water to a concentration of $1 \mathrm{mg} \cdot \mathrm{mL}^{-1}$. Stock standard solutions of tartaric acid, malic acid, lactic acid, acetic acid and citric acid were dissolved in ultrapure water to a concentration of $10 \mathrm{mg} \cdot \mathrm{mL}^{-1}$. They were stored in darkness at $+4^{\circ} \mathrm{C}$ until analyzed. The calibration curves were prepared by diluting the stock solution in the mobile phase to furnish solutions with final concentrations of 150-1000 $\mu \mathrm{g} \cdot \mathrm{mL}^{-1}$ for acetic acid and citric acid; 100-1000 $\mu \mathrm{g} . \mathrm{mL}^{-1}$ for malic acid and lactic acid; 50-1000 $\mu \mathrm{g} \cdot \mathrm{mL}^{-1}$ for tartaric acid; 2.0-100 $\mu \mathrm{g} \cdot \mathrm{mL}^{-1}$ for ascorbic acid; 5-80 $\mu \mathrm{g} . \mathrm{mL}^{-1}$ for oxalic acid; 0.7$16 \mu \mathrm{g} . \mathrm{mL}^{-1}$ for fumaric acid.

\section{Sample Preparation}

The orange fruit juice was obtained by cutting the fruit in half and careful hand-squeezing to obtain the juice. The juice was filtered to remove pulp and seeds. The freshly squeezed juice was centrifuged at $13200 \mathrm{rpm}$ for $15 \mathrm{~min}$. The commercial orange juice was directly centrifuged at 13200 rpm for 15 min. The supernatant was diluted 1:10 and 1:5 with mobile phase for determination of organic acids. The dilutions were membrane filtered $(0.45 \mu \mathrm{m})$ before injection. 


\section{Instrumentation and Chromatographic Conditions}

The integrated high performance liquid chromatography system (LC 1100, HewlettPackard, USA) is equipped with a diode-array UV detector, a quarternary pump, a degasser, an autosampler, an injector with $20 \mu \mathrm{L}$ loop, and a column oven. The separation was carried out using Inertsil ODS- 4 reverse phase $\mathrm{C} 18$ column ( 4 $\mathrm{mm} \times 250 \mathrm{~mm}, 5 \mu \mathrm{m}$ ).

The mobile phase was a $10 \mathrm{mM} \mathrm{KH}_{2} \mathrm{PO}_{4}$ aqueous solution adjusted to $\mathrm{pH} 2.2$, to which was added $10 \%$ $(\mathrm{v} / \mathrm{v})$ orthophosphoric acid. The mobile phase was vacuum-filtered through a $0.45 \mu \mathrm{m}$ nylon filter and degassed on-line by micro vacuum degasser. The chromatographic separation of these compounds performed at room temperature. Analysis was run at flow rate of $1 \mathrm{~mL}$. $\mathrm{min}^{-1}$ with 10 min run time. For the simultaneous detection of the eight analytes, the detector was set at $\lambda=245 \mathrm{~nm}$ for ascorbic acid and $\lambda=210 \mathrm{~nm}$ for the other organic acids. The injection volume was $20 \mu \mathrm{L}$.

\section{Validation Procedure}

A full validation of assay consisting of selectivity, linearity, lower limit of detection and quantitation (LOD and LOQ), intraday and interday accuracy and precision of the method was performed according to the ICH description [9].

\section{RESULTS and DISCUSSION}

The first step of the study was the optimization of the chromatographic conditions. The effect of phosphate buffer concentration $(5,10,20$ and 30 $\mathrm{mM})$ and $\mathrm{pH}(2.2,2.4,2.6)$ on the retention time of mixture was investigated. The concentration of the phosphate buffer solution was chosen as 10 $\mathrm{mM}$ and $\mathrm{pH}$ as 2.2 for optimum separation (Figure 1).

Quantifications of organic acids were based on the calibration curves constructed under optimum conditions as the peak areas of analyzed substance. Linearity of the method was determined by performing injections at six different concentration levels in the linear range over 6 different days. Retention time (RT), linear range, $\mathrm{R}^{2}$, limit of detection (LOD) and limit of quantification values were listed in Table 1.

Precision was expressed as the relative standard deviation of the control sample concentrations. Three different concentrations of standard solutions were analyzed six consecutive days and six times within the same day. Intra-assay (intra-day) precisions were ranged from $0.57-5.52 \%$ for oxalic acid, tartaric acid, malic acid, ascorbic acid, lactic acid, acetic acid, citric acid and fumaric acid. Interassay precisions values were in the range of 0.87 to $6.45 \%$ for them.

The accuracy of the proposed procedure was evaluated by means of recovery experiments. To demonstrate the accuracy of the method, a samp-

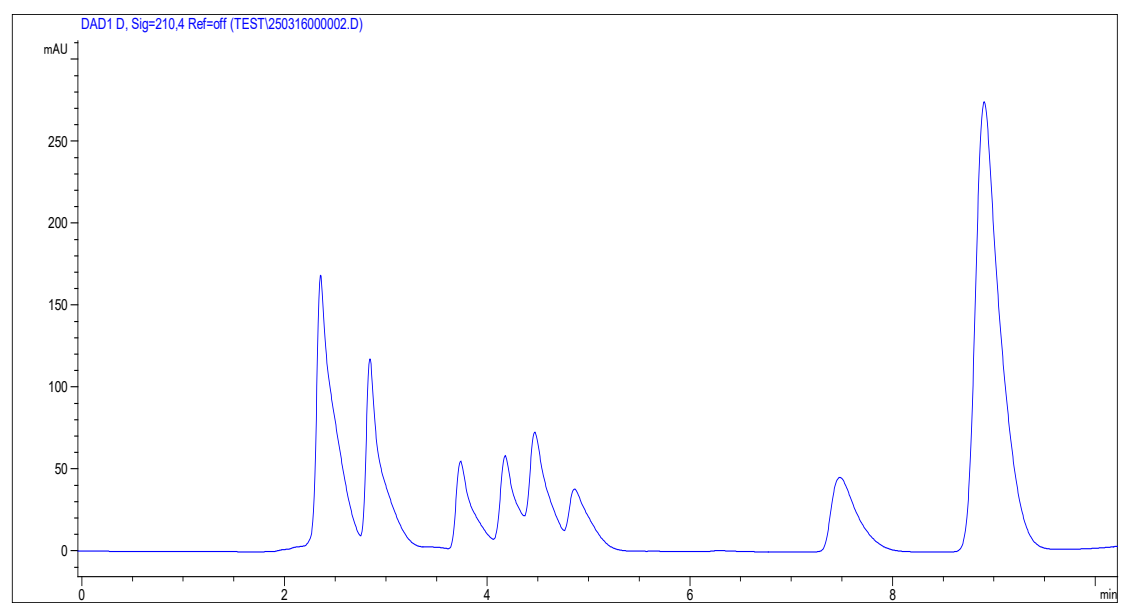

Figure 1. A typical chromatogram of organic acid standards. 1, oxalic acid; 2, tartaric acid; 3, malic acid; 4, ascorbic acid; 5, lactic acid; 6 , acetic acid; $7, \quad$ citric acid; 8 , fumaric acid. 
Table 1. Linearity study results $(n=6)$.

\begin{tabular}{|c|c|c|c|c|c|c|c|c|c|}
\hline Compound & $\begin{array}{l}\text { Retention } \\
\text { time (min) }\end{array}$ & $\begin{array}{l}\text { Range } \\
\left(\mathrm{mg} \cdot \mathrm{L}^{-1}\right)\end{array}$ & $\begin{array}{l}\text { Calibration curve } \\
(y=m x \pm n)\end{array}$ & $\begin{array}{l}\text { RSD } \\
(\%) \\
\text { (slope) }\end{array}$ & $\mathrm{R}^{2}$ & $\begin{array}{l}\mathrm{LOQ} \\
\left(\mathrm{mg} \cdot \mathrm{L}^{-1}\right)\end{array}$ & $\begin{array}{l}\text { RSD } \\
(\%)\end{array}$ & $\begin{array}{l}\text { LOD } \\
\left(\mathrm{mg} \cdot \mathrm{L}^{-1}\right)\end{array}$ & $\begin{array}{l}\text { RSD } \\
(\%)\end{array}$ \\
\hline Oxalic acid & $2.20 \pm 0.02$ & $5-80$ & $y=24.289 x+10.581$ & 2.05 & 0.997 & 5 & 4.91 & 1 & 5.44 \\
\hline Tartaric acid & $2.87 \pm 0.01$ & $50-1000$ & $y=2.078 x+10.391$ & 5.43 & 0.999 & 50 & 1.60 & 10 & 5.19 \\
\hline Malic Acid & $3.75 \pm 0.01$ & $100-1000$ & $y=1.094 x-762$ & 3.47 & 0.999 & 100 & 1.60 & 20 & 2.51 \\
\hline Ascorbic Acid & $4.20 \pm 0.02$ & $2-80$ & $y=72.47 x-2.935$ & 2.77 & 0.999 & 2 & 0.87 & 0.5 & 4.51 \\
\hline Lactic Acid & $4.47 \pm 0.03$ & $100-1000$ & $y=0.891 x+1.500$ & 3.52 & 0.999 & 100 & 1.04 & 20 & 0.85 \\
\hline Acetic Acid & $4.85 \pm 0.03$ & $150-1000$ & $y=0.902 x+0.552$ & 3.11 & 0.997 & 150 & 2.16 & 50 & 2.28 \\
\hline Citric Acid & $7.49 \pm 0.02$ & $150-1000$ & $y=1.390 x-6.207$ & 3.10 & 0.999 & 150 & 1.75 & 50 & 2.14 \\
\hline Fumaric Acid & $8.93 \pm 0.03$ & $0.7-16$ & $y=217.835 x+0.586$ & 3.11 & 0.999 & 0.7 & 2.24 & 0.2 & 3.88 \\
\hline
\end{tabular}

le of fruit juice was analysed before and after the addition of known amounts of the organic acids under study. The supernatant was diluted 1:10 before analysis. The results obtained clearly demonstrate the accuracy of the method (Table 2).

The optimized and validated method was applied for determination of organic acids in natural and commercial orange juices (Figure 2 ). All samples were run in triplicate $(n=3)$. The results obtained were shown in Table 3.

\section{CONCLUSION}

A basic and reliable HPLC method has been developed and validated for the determination of organic acids in natural and commercial orange juices. Compared to the other reported ones, the developed method offers fast separation and simple sample preparation needing only centrifugation, dilution and filtration before injection.

In orange juices, the most abundant organic acid was citric acid ranging from 5.63 to 5.90 g. $\mathrm{L}^{-1}$. The second most abundant organic acid is malic acid ranging from 0.50 to $1.29 \mathrm{~g} . \mathrm{L}^{-1}$. Orange juices are good sources of ascorbic acid (0.21-0.48 g.L L $^{-1}$. Commercial orange juices contain lower amount of ascorbic acid, malic acid and oxalic acid compared
Table 2. Recovery of organic acids spiked fruit juice samples.

\begin{tabular}{|c|c|c|c|c|}
\hline $\begin{array}{l}\text { Organic } \\
\text { acids }\end{array}$ & $\begin{array}{c}\text { Initial } \\
\text { amount } \\
\left.\text { (mg. } \mathrm{L}^{-1}\right)\end{array}$ & $\begin{array}{l}\text { Added } \\
\left(\mathrm{mg}^{\left.-\mathrm{L}^{-1}\right)}\right.\end{array}$ & $\begin{array}{l}\text { Found } \\
\left(\mathrm{mg}^{\left.-L^{-1}\right)}\right.\end{array}$ & $\begin{array}{c}\text { Recovery } \\
\text { (\%) }\end{array}$ \\
\hline \multirow{2}{*}{$\begin{array}{l}\text { Oxalic } \\
\text { acid }\end{array}$} & \multirow[b]{2}{*}{75.14} & 25 & 106.96 & 106.81 \\
\hline & & 50 & 131.80 & 105.32 \\
\hline \multirow{2}{*}{$\begin{array}{c}\text { Tartaric } \\
\text { acid }\end{array}$} & \multirow{2}{*}{ n.d. } & 250 & 258.63 & 103.45 \\
\hline & & 500 & 532.65 & 106.53 \\
\hline \multirow{2}{*}{$\begin{array}{l}\text { Malic } \\
\text { Acid }\end{array}$} & \multirow{2}{*}{596.54} & 250 & 851.79 & 100.62 \\
\hline & & 500 & 1128.23 & 102.89 \\
\hline \multirow{2}{*}{$\begin{array}{c}\text { Ascorbic } \\
\text { Acid }\end{array}$} & \multirow{2}{*}{344.30} & 50 & 376.00 & 95.36 \\
\hline & & 80 & 395.28 & 93.05 \\
\hline \multirow{2}{*}{$\begin{array}{l}\text { Lactic } \\
\text { Acid }\end{array}$} & \multirow{2}{*}{ n.d. } & 500 & 528.25 & 105.65 \\
\hline & & 1000 & 1063.50 & 106.35 \\
\hline \multirow{2}{*}{$\begin{array}{c}\text { Acetic } \\
\text { Acid }\end{array}$} & \multirow{2}{*}{ n.d. } & 250 & 246.83 & 98.73 \\
\hline & & 500 & 498.25 & 99.65 \\
\hline \multirow{2}{*}{$\begin{array}{l}\text { Citric } \\
\text { Acid }\end{array}$} & \multirow{2}{*}{5626.67} & 250 & 5553.45 & 94.50 \\
\hline & & 500 & 5746.20 & 93.79 \\
\hline \multirow{2}{*}{$\begin{array}{c}\text { Fumaric } \\
\text { Acid }\end{array}$} & \multirow{2}{*}{1.95} & 5 & 7.21 & 103.72 \\
\hline & & 10 & 12.10 & 101.24 \\
\hline
\end{tabular}

n.d.-not detected. 

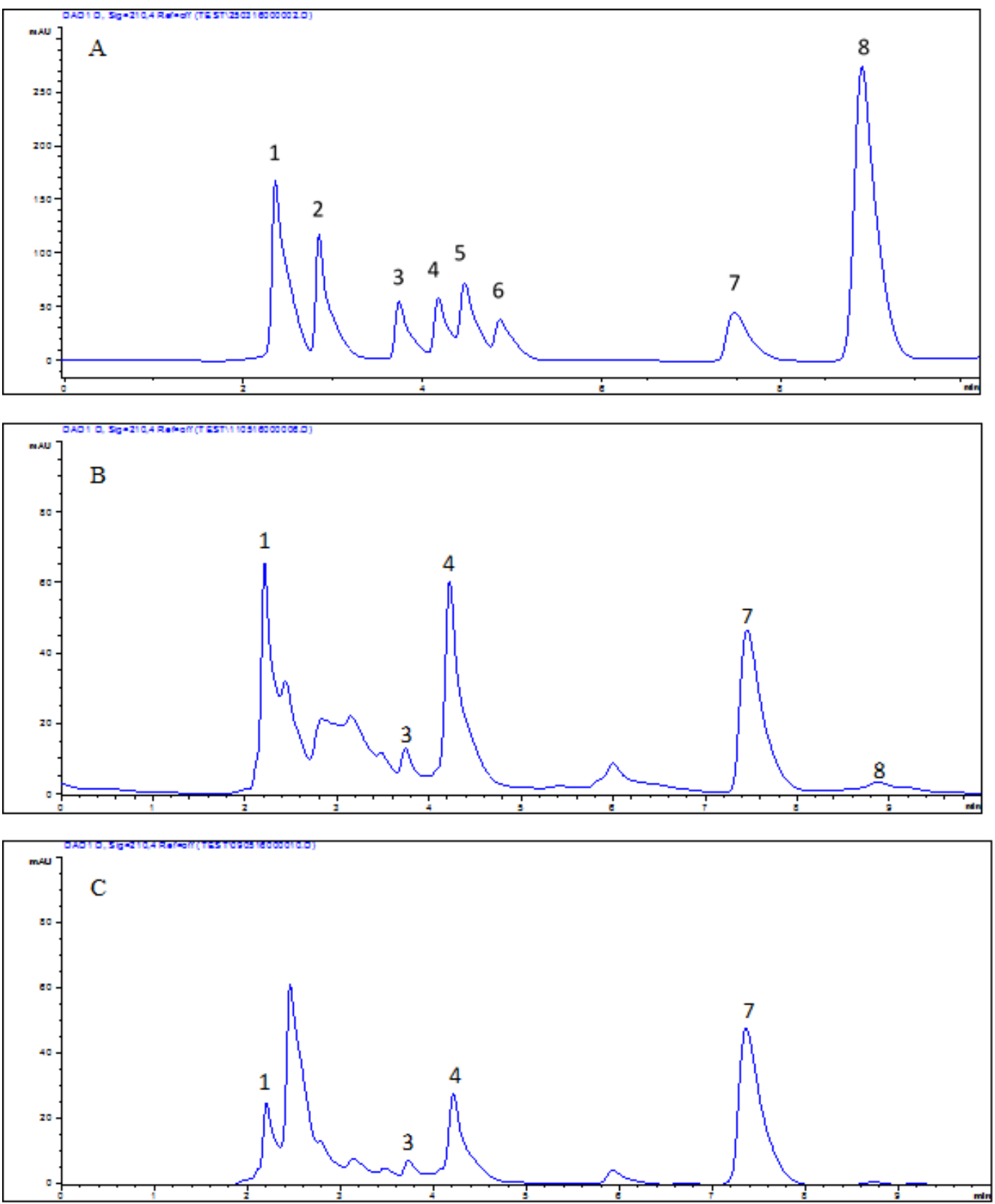

Figure 2. A. Chromatogram of standards of analyte at $210 \mathrm{~nm}$. The peaks correspond to: 1, oxalic acid; 2, tartaric acid; 3, malic acid; 4, ascorbic acid; 5, lactic acid; 6, acetic acid; 7, citric acid; 8, fumaric acid. B. Chromatogram of freshly squeezed orange juice $C$. Chromatogram of commercial orange juice.

Table 3. Organic acid composition of commercial and natural fruit juices obtained by HPLC method*.

\begin{tabular}{|c|c|c|c|c|}
\hline Organic acids & $\begin{array}{l}\text { Commercial } \\
\text { fruit juice A } \\
\left(\mathrm{mg} .100 \mathrm{~mL}^{-1}\right)\end{array}$ & $\begin{array}{l}\text { Commercial } \\
\text { fruit juice B } \\
\left(\mathrm{mg} .100 \mathrm{~mL}^{-1}\right)\end{array}$ & $\begin{array}{c}\text { Natural } \\
\text { orange juice } \\
\left.\text { (mg.100 } \mathrm{mL}^{-1}\right)\end{array}$ & $\begin{array}{c}\text { Natural } \\
\text { orange juice } \\
\text { (mg. } 100 \mathrm{~mL}^{-1} \text { ) }\end{array}$ \\
\hline Oxalic acid & $9.45 \pm 0.73$ & $7.51 \pm 0.57$ & $23.78 \pm 2.30$ & $16.89 \pm 1.64$ \\
\hline Malic acid & $50.06 \pm 2.32$ & $59.65 \pm 1.94$ & $128.85 \pm 2.52$ & $134.76 \pm 1.86$ \\
\hline Ascorbic acid & $21.17 \pm 1.35$ & $34.43 \pm 1.51$ & $47.81 \pm 0.98$ & $47.53 \pm 1.91$ \\
\hline Citric acid & $590.05 \pm 21.23$ & $562.67 \pm 19.47$ & $581.23 \pm 15.44$ & $579.35 \pm 17.54$ \\
\hline Fumaric acid & n.d. & n.d. & $0.2 \pm 0.02$ & $0.15 \pm 0.01$ \\
\hline
\end{tabular}

* Results are expressed as mean \pm SD (standard deviation) $(n=3)$. 
with natural orange juices. Fumaric acid was found only in natural orange juices. Citric acid contents were similar in both natural and commercial orange juices. According to this research the orange juices should be consumed freshly.

\section{ACKNOWLEDGMENT}

This research was supported by the Inonu University Research Council (Project no: 2016/148).

\section{References}

1. V. Nour, I. Trandafir, and M.E. Ionica, HPLC organic acid analysis in different citrus juices under reversed phase conditions, Not. Bot. Hort. Agrobot. Cluj., 38 (2010) 44-48.

2. R. Scherer, A.C.P. Rybkaa, C.A.Ballusa, A.D. Meinharta, J.T. Filhob, H.T. Godoy, Validation of a HPLC method for simultaneous determination of main organic acids in fruits and juices, Food Chem., 135 (2012) 150-154.

3. G.H. Shui, and L.P. Leong, Separation and determination of organic acids and phenolic compounds in fruit juices and drinks by highperformance liquid chromatography, J Chromatogr. A, 977 (2002) 89-96.
4. S.C. Cunha, J.O. Fernandes, and I.M.P.L.V.O. Ferreira, HPLC/UV determination of organic acids in fruit juices and nectars, Eur. Food Res. Technol., 214 (2002) 67-71.

5. A. Kotani, Y. Miyaguchi, E. Tomita, K. Takamura and F. Kusu, Determination of organic acids by high-performance liquid chromatography with electrochemical detection during wine brewing, J. Agric. Food Chem., 52 (2004) 1140-1144.

6. P. Flores, P. Hellín, J. Fenoll, Determination of organic acids in fruits and vegetables by liquid chromatography with tandem-mass spectrometry, Food Chem., 132 (2012) 1049-1054.

7. F. Chinnici, U. Spinabelli, C. Riponi, A. Amati, Optimization of the determination of organic acids and sugars in fruit juices by ion-exclusion liquid chromatography, J. Food Comp. Anal., 18 (2005) 121130.

8. H. Kelebek, S. Selli, A. Canbas, T. Cabaroglu, HPLC determination of organic acids, sugars, phenolic compositions and antioxidant capacity of orange juice and orange wine made from a Turkish cv. Kozan, Microchem. J., 91 (2009) 187-192.

9. $\mathrm{ICH}$ Steering Committee, Validation of analytical procedures: text and methodology, Q2 (R1) (2005) $1-17$. 